\title{
Adenomatous Polyposis Coli Protein 2
}

National Cancer Institute

\section{Source}

National Cancer Institute. Adenomatous Polyposis Coli Protein 2. NCI Thesaurus. Code C21324.

Adenomatous polyposis coli protein 2 (2303 aa, $\sim 244 \mathrm{kDa}$ ) is encoded by the human APC2 gene. This protein is involved in the regulation of catenin beta-1 turnover. 